\title{
Economics of Non-Timber Forest Production Promotion and Marketing: A case study from Malekhukhola Watershed of Dhading District, Nepal
}

Bishnu Hari Pandit, Ph.D. ${ }^{1}$

\begin{abstract}
This article examines the prospects of promoting NTFPs in the mountains of Nepal. Despite being profitable, the farmers do not readily accept cultivating NTFP species on their farmlands on a large scale. The analyses revealed that domestication of MAP species is significantly influenced by various factors such as, knowledge and skill required for domestication, frequency of visits to forest, the length of fallow period, size of upland terraces, cattle and goat herd size, accessibility to forest, inappropriate permit system, difficult trading system and market uncertainty. The inappropriate NTFP permit system, difficult trading system and free access to forest have negatively influenced domestication of MAP species. Overall, lack of a favorable institutional environment has been the major factor constraining the integration of NTFP species into farmland on a large scale by farmers. Policy recommendations include handing over the use and management responsibility to local people, to that prevent open access status of national forests, providing NTFP collection permits to local residents, lobbying for amending inappropriate policies, rules and regulations, promoting group marketing and adaptive collaborative forest management approach to community forestry.
\end{abstract}

Key Words: NTFP collection, Marketing, Domestication, Factors affecting MAP domestication

\section{Introduction}

The role of NTFPs in conservation and economic development of rural poor people in Nepal and elsewhere in the region has been increasingly recognized by many development professionals and scientists in the last two decades (De Beer and Mcdermott, 1996; Mittelman et al., 1997; Arnold and Perez, 1998). Majority of people in some mountain watersheds of developing countries depend on Medicinal Aromatic Plants (NTFP) as supplementary source of cash income for fulfilling their subsistence requirements (ANSAB 1997, Arnold and Perez 1998, Ingles 1998, Olsen, 1998, Pandit 2001). The mountain watersheds of Nepal are not an exception. Majority of people in some mountain watersheds of Nepal rely heavily on cash income from NTFPs available in national and community forests, as the small amount of return from agriculture, which is the main economic activity from the perspective of household labour employment, is not adequate to meet their subsistence needs. More recently, cash income from NTFPs has increased considerably with growing commercialisation of rural economies, arising from gradually expanding market linkages. Both the national economy and the people have benefited considerably from NTFP (Edwards, 1996; Olsen, 1998).

\footnotetext{
ICIMOD,bpandit@icimod.org
} 
With commercialization of NTFPs, the NTFP resources are being gradually depleted, and some species are threatened. In parallel with the institutionalization of a management system geared to protect and conserve NTFPs while facilitating their prudent use, and the establishing of an improved system for the marketing of NTFPs that ought to secure a better deal for local collectors, the domestication of NTFPs is essential to accomplish the above stated objectives. The question arises what farmers think about the domestication of NTFPs, whether some farmers already have domesticated some NTFP species, what factors influence domestication, and to what extent it can create benefits to farmers who, by and large, have a choice between cultivating field crops and growing NTFPs.

This study is a step forward in the pursuit of addressing the above gaps. It examines equity in distribution of income from NTFPs among different stakeholders including NTFP collectors and traders. Particularly NTFP collectors' income is further analyzed according to their socioeconomic characteristics and possibility of expansion of NTFP domestication were examined by comparing the costs and benefits of growing NTFPs in private farmlands.

This paper is part of the author's Ph.D. thesis conducted in Malekhukhola watershed of Dhading District of Nepal. The objectives of the study were to assess the NTFP collection system, assess NTFP domestication, investigate NTFP contribution to household economy, analyze NTFP marketing margin, explore the socio-economic and institutional factors influencing the domestication of Medicinal Aromatic Plants (MAPs) and suggest strategies for NTFP promotion in mountains of Nepal.

\section{Study Area}

\section{Location}

This study was carried out in the Malekhu Khola watershed of Dhading district, Nepal, where a considerable proportion of households are engaged in NTFP collection and trading. With an area of 10,426 ha, this watershed can be divided into two elevational zones: the lower (418$800 \mathrm{~m})$ and the upper $(801-2400 \mathrm{~m})$ Malekhu Khola, as these two zones vary in terms of biophysical and socio-economic features. The upper zone is characterised by a cool climate throughout the year; the lower zone's climate is subtropical, with a warm summer season and a cool winter season.

\section{Forests in Malekhu khola watershed}

From the perspective of management system, forests in the study area can be broadly classified into three types: national forest, community forest and religious forest. National forests are directly controlled by the Department of Forests (DoF). Community forests fall into two groups: formal and informal community forests according to the legal status of use and management rights. Use and management rights of formal community forests have been transferred to local communities by the District Forest Office (DFO). In regard to informal community forest, such rights have not yet been formally transferred to local communities, though they are enjoying such rights for a long period. Religious or sacred forests are national 
forests, which are being protected by people because of the belief that they are home to revered spirits.

More than two-thirds of the upper zone is covered with forest comprising several species of economically valuable NTFP; of which more than 95 percent is under direct government control. In the lower zone, more than half of the national forest has been handed over to local communities as community forest. Out of eight community forests handed over to local communities in the lower zone, NTFP management plan has been prepared for just one community forest. The important NTFP collected in the study area include Asparagus racemosus, Swertia chirayita, Berginia ciliata, Rubia manjith, Nardostachys grandiflora, Parmelia nepalensis and Tinospora cardifolia. Among these species, Asparagus and Tinospora are common in the lower zone, while others are mainly found in the upper zone.

\section{Methodology}

Data were collected through a survey of 324 households, traders' survey, field observation and group discussions held with NTFP collectors, as well as traders at village, road head markets of the study area. The household survey covered a wide array of matters related to household characteristics, occurrence of NTFP species, preferences and willingness of farmers to grow NTFPs, reasons for not domesticating preferred and high value NTFPs in privately owned farmlands, and farmers' initiatives geared to grow NTFPs. Besides, participatory resource assessment tools including community resource assessment ranking, stakeholders mapping and well being ranking were used. Biophysical data recorded from seven farmers' trial plots on two important NTFPs species, Swertia Chirayita and Asparagus racemosus provided information on cost and benefit of both field crop cultivation and NTFPs.

Following the methodology developed by Olsen (1998) profit and marketing margin analyses were done for the ten prominent NTFPs traded to India to find out particularly collectors' relative share of the income earned through the trade. Factor analysis was done to explore the possibility of domesticating NTFPs in privately owned farmlands.

\section{Result and Discussion}

\section{NTFP collection systems}

Government and community forests in the study area are the natural habitat of many NTFP species. A total of 16 NTFP species have been collected and traded from the study area to India.Of the 16 species, three belong to the category of clump or bush species (Dendrocalamus strictus, Arundinaria intermedia and Thysanolaena maxima), six to that of tree species (Bassia butyracea, Emblica officinalis, Terminalia chebula, Cinnamomum tamala, Myrica esculenta and Zanthoxylum armatum) and seven to that of medicinal aromatic plant (NTFP) species (Nardostachys grandiflora, Swertia chirayita, Rubia manjith, Berginia ciliata, Tinospora cordifolia, Asparagus racemosus and Parmelia nepalensis) (Table 1). 
Table 1: Major NTFPs collected and proportions of households involved in collection

\begin{tabular}{|c|c|c|c|c|}
\hline \multirow[t]{2}{*}{ NTFP species } & \multicolumn{2}{|c|}{ Upper zone $\mathrm{n}=152$} & \multicolumn{2}{|c|}{ Lower zone $n=172$} \\
\hline & Qty & $\% \mathrm{HH}$ & Qty & $\% \mathrm{HH}$ \\
\hline A. Tree species (kg) & & & & \\
\hline 1. Cinnamomum tamala (cinnamon) & 235 & 18 & 113 & 13 \\
\hline 2. Myrica esculenta (box myrtle) & 4590 & 43 & 390 & 3 \\
\hline 3. Zanthoxylum armatum (timur) & 466 & 43 & 23 & 9 \\
\hline 4. Bassia butyraceae (chiuri) & 544 & 10 & 1826 & 28 \\
\hline 5. Enblica officinalis (amala) & 78 & 5 & 1055 & 38 \\
\hline 6. Terminalia species (bastard myrobalan) & 59 & 3 & 208 & 29 \\
\hline $\begin{array}{l}\text { B. Clump or bush type (culm or broom } \\
\text { numbers) }\end{array}$ & 111 & 12 & 293 & 22 \\
\hline 1. Dendrocalamus species (large bamboo) & & & & \\
\hline $\begin{array}{l}\text { 2. Arundinaria intermedia (small } \\
\text { bamboo) }\end{array}$ & 4410 & 62 & 2070 & 20 \\
\hline 3. Thy samolaena moxima (broom grass) & 3063 & 47 & 1816 & 28 \\
\hline C. Medicinal aromatic plants - NTFPs & & & & \\
\hline 1. Nordostac hys grandiflora (nardus not) & 246 & 6 & 5 & 1 \\
\hline 2. Swertia chirayita (chiretta) & 1708 & 43 & 162 & 2 \\
\hline 3. Rubia manjith (Indian madder) & 547 & 18 & 50 & 1 \\
\hline 4. Bergenia ciliata (rockfoil) & 722 & 28 & 15 & 3 \\
\hline 5. Tinospora cordifolia (gurjo) & 26 & 3 & 332 & 16 \\
\hline 6. Asparagus racemosus (wild asparagus) & 1852 & 25 & 1530 & 31 \\
\hline 7. Parmelia nepalensis (lichen) & 2285 & 26 & 400 & 3 \\
\hline
\end{tabular}

Source: Field survey, 2001, HH = Household

NB: Qty = Quantity in weight or volume measurements, as indicated.

Of these NTFPs, the three NTFP species, (1) Nardostachys grandiflora, (2) Swertia chirayita and (3) Asparagus racemosus were in high market demand. Taking advantage of this opportunity, people from both within and outside the watershed have been collecting and trading these NTFPs with little concern for their conservation. As a result, all commercially valuable NTFPs in both government and community forests are under threat of degradation (Olsen, 1998; Pandit, 2001; Pandit and Thapa, 2004). This problem is more severe in government forests that are open to everyone than in community forests, which are restrictively managed by local communities. The root of the problem appeared to be the inadequacy of the national forestry policy to equally cover the timber and non-timber components of forest resources. At the local level, this lack of consistency has led to failure of whatever enforcement of rules and regulations.

Moreover, the District Forest Office (DFO) has not been enabled to protect government forests under its purview, in the absence of legal authorization and lacking qualified manpower as well as appropriate infrastructure. In short, the DFO has not taken a pro-active stance by paying attention to the conservation of NTFPs and concentrated on reacting by penalizing 
users of NTFPs. All resources including water, livestock, land, timber and NTFPs are depleting. However, NTFP is degrading more than other resources (Fig 1).

Villagers expressed apprehension about the prospect of NTFPs to be managed by their CFUGs, fearing that such resolve would deprive them of direct personal benefits, as had happened in the case of highvalue trees cut in their community

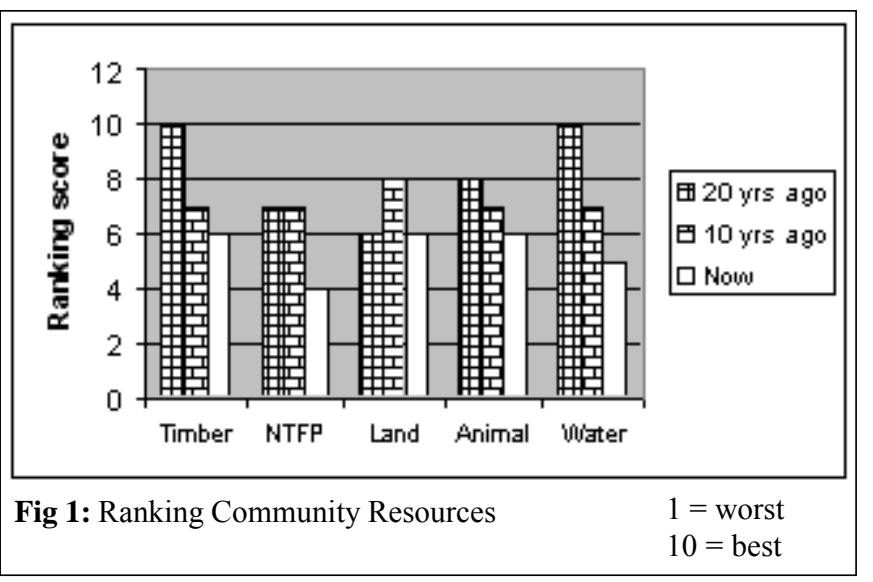
forests that no longer generates individual income from the sales of timber. It was for this reason that even local people holding CFUG membership opposed the regulating of the management and collection of NTFPs. In the absence of any NTFP conservation rules and guidelines, the DFO staff would not make any efforts to raise awareness among local people of the importance of prudent management and sustainable use of NTFPs; much less would officers encourage users to adopt salutary practices of collecting NTFPs.

\section{NTFP contribution to household economies}

As discussed earlier, NTFP has played a significant role in contribution of household economies. In areas with marketing facility, local people are selling raw or processed NTFPs, including handicrafts and furniture made from bamboo and rattan, for cash income required to fulfill their household needs. Average household earnings from wild NTFPs in the upper zone are almost three times higher than in the lower zone. Operating small landholding and scarce non-farm employment opportunities, almost all households of low-income group (95\%) were involved in NTFP collection in the upper zone. Even in the lower zone, majority of households (70\%) of this group were collecting NTFPs. The proportion of households involved in collecting NTFPs by other two income groups (middle and high) was considerably low (Table 2).

Table 2: Cash earnings from NTFPs collected from forest by household income classes

\begin{tabular}{|l|c|c|c|c|}
\hline \multicolumn{1}{|c|}{ Household income classes } & \multicolumn{2}{c|}{ Upper zone } & \multicolumn{2}{c|}{ Lower zone } \\
\cline { 2 - 5 } & Rs HH $^{\mathbf{1}}$ & $\mathbf{\%}$ & Rs HH $^{\mathbf{1}}$ & \% \\
\hline Low (annual income of up to Rs. 10,000) & 2346 & $53(95)$ & 878 & $23(70)$ \\
Middle (annual income Rs. 10,001 to & 1913 & $33(90)$ & 815 & $39(62)$ \\
20,000) & & & & \\
\hline High (annual income above Rs. 20, 000) & 1007 & $14(46)$ & 610 & $38(46)$ \\
Average eamings per household & 2018 & 84 & 750 & 57 \\
& $(14 \%)$ & & $(4 \%)$ & \\
\hline
\end{tabular}

Source: Field survey: 2001. $\mathrm{HH}=$ Household

NB: Figures in parentheses show the percentages of households engaged in collecting NTFPs within each group. 
The low-income group of people earned the highest income from NTFPs, while high income group earned the least, as they have relatively large better quality lands that are used for growing vegetables and other cereals. The middle class people on the other hand have taken advantage from both NTFPs and farm crops. NTFPs have so far helped particularly the lowest income group, including chepang and tamang to fulfill their subsistence requirements considerably. This group is therefore, going to be most adversely affected as NTFPs are undergoing degradation due to unsustainable collection practices arisen from inappropriate institutional systems and people's carelessness about the impact of their practices. People are concerned about sustainable conservation of NTFPs. However, they are constrained due to lack of incentives. Local people will not take the initiative towards sustainable use and management of NTFPs as long as they are not assured of personal benefits. In view of this, the concerned people either in government forest or in community forests have to be provided with the opportunity to get direct benefits from NTFP as a reward for their contribution to the program.

\section{NTFP marketing}

Of the 16 NTFP species listed in the preceding section, this section analyzes the profit and marketing margins of ten (10) selected NTFP species traded to India. The species included in the marketing margin analysis are Swertia chirayita, Asparagus racemosus, Nardostachys grandiflora, Emblica officinalis, Tinospora cordifolia, Parmelia nepalensis, Zanthoxylum armatum, Rubia manjith, Bergenia ciliata, Cinnamomum tamala and Tinospora cardifolia. Most of these are medicinal aromatic plants (MAPs), except Emblica officinalis and Zanthoxylum armatum. The other six NTFPs were not included in the marketing margin analysis because they were sold only at the local market.

The three intermediaries marketing raw materials and / or goods based on NTFPs are the local, village-based traders, the road-head traders handling either small quantities or bulk, and the wholesalers. Many products reach the Indian market. In principle, primary collectors could sell NTFPs to any of these intermediaries. For practical reasons, including material and financial interdependency at local level, distance between forests and local traders' village based or road-heads, and mode of transportation by far most collectors would sell their NTFPs to village-based and / or road-head traders. Virtually no household in the watershed under study would sell NTFPs to wholesalers and definitely not to any traders across the national border, in India.

NTFP trading is not an economically attractive activity for collectors. In most instances there is little left as profit if the cost of processing, which is mainly in the form of time spent by household labor on cleaning, drying and sorting out unusable parts, is taken from the sales value of NTFP. Consistent with Dixon et al (1989), unskilled labor cost is not included in the total costs, as there is no alternative work available for such laborers in the study area. In view of very high processing cost of most NTFPs, it is plausible to say that the profit margin would yield negative values if the cost of household labor employed in NTFP collection were taken into account. Despite this, settlers are engaged in this activity, as there are no alternative income opportunities. Given their very poor economic conditions, even a small amount of 
earnings, which may only be payment for the laborer employed in NTFP processing, has a significant value, as it helps to fulfill some subsistence requirements. Without inclusion of unskilled labor cost, collectors receive the highest percentages of profit margins from three species, namely, Swertia, Nardostachys and Parmelia in the upper zone and two species, Swertia and Asparagus in the lower zone (Table 3).

Because of high cash value, Swertia and Nardostachys have higher profit margins compared to other species. The high royalty rate of Parmelia species, which need not to be paid by collectors but has to be paid either by village trader or road head trader, made possible for collectors to get higher margin in the upper zone. It is interesting to note that the same species, Parmelia is not providing high profit margin in the lower zone. It is attributed to the fact that collectors have to go to upper zone to collect this species, which involves high transportation cost.

Table 3: Profit and marketing margins of ten selected NTFPs at different trading levels

\begin{tabular}{|c|c|c|c|c|c|c|c|c|c|c|c|}
\hline \multirow{2}{*}{\multicolumn{2}{|c|}{$\begin{array}{l}\text { Levels of the trade } \\
\text { channel }\end{array}$}} & \multicolumn{10}{|c|}{ Selec ted NTFP species } \\
\hline & & $S c$ & $A r$ & $P_{n}$ & $C t$ & $R m$ & $Z a$ & $B c$ & Eo & $T c$ & $\mathrm{Ng}$ \\
\hline Collectors & $\begin{array}{l}\text { Profit margin } \\
(\%)\end{array}$ & 88 & 20 & 40 & 18 & 22 & 11 & 18 & 5 & 8 & 47 \\
\hline $\begin{array}{l}\text { Village } \\
\text { traders }\end{array}$ & $\begin{array}{l}\text { Profit margin } \\
(\%)\end{array}$ & 7 & 6 & 20 & 10 & 12 & 28 & 7 & 4 & 20 & 4 \\
\hline $\begin{array}{l}\text { Road-head } \\
\text { traders }\end{array}$ & $\begin{array}{l}\text { Profit margin } \\
(\%)\end{array}$ & 22 & 22 & 40 & 2 & 10 & 15 & 20 & 9 & 16 & 39 \\
\hline Wholesalers & $\begin{array}{l}\text { Profit margin } \\
(\%)\end{array}$ & 32 & 29 & 6 & 13 & 31 & 2 & 8 & 8 & 7 & 8 \\
\hline $\begin{array}{l}\text { Indian } \\
\text { traders }\end{array}$ & $\begin{array}{l}\text { Profit margin } \\
(\%)\end{array}$ & 22 & 23 & 13 & 5 & 8 & 8 & 10 & 2 & 6 & 5 \\
\hline Collectors' & A. $(c / w)^{*} 100$ & 28 & 31 & 20 & 60 & 38 & 41 & 46 & 58 & 40 & 43 \\
\hline $\begin{array}{l}\text { marketing } \\
\text { margin (\%) }\end{array}$ & B. $(c / \text { th })^{*} 100$ & 44 & 47 & 25 & 73 & 60 & 44 & 55 & 69 & 48 & 48 \\
\hline
\end{tabular}

Source: Field survey: 2001.

Abbreviations:

$\mathrm{c}=$ collectors,

$S c=$ Swertia chirayita,

$\mathrm{rh}=$ road head traders and

$\mathrm{w}=$ wholesalers

$C t=$ Cinnamomum tamala,

Ar=Asparagus racemosus,

Pn=Parmelia nepalensis,

Rm= Rubia manjith,

Za=Zanthoxylum armatum,

$B c=$ Bergenia celiata,

Eo= Emblica officinalis,

Tc = Tinospora cardifolia,

$\mathrm{Ng}=$ Nardostachys grandiflora .

The marketing margin analysis shows that with the exception of a few NTFPs, the major proportions of the final sales value of all NTFPs are taken by traders in villages, road heads and cities (Table 3). The villagers who devote time and labor to collecting and processing NTFPs are receiving only a small percentage of the total benefit generated by this activity (Table 3). This is an indication of an inefficient marketing system (Sidhu, 1997: Ellis, 1992). 
Several factors including the lack of collectors' awareness of market prices, traders' monopoly in marketing, distant and difficult transport systems, post harvest losses, legal constraints and poverty are responsible for this.

\section{NTFP domestication}

The frequently asked questions about NTFP domestication are: what farmers think about the domestication of NTFPs? Whether some farmers already have domesticated some NTFP species, what factors influence domestication, and to what extent it can create benefits to farmers who, by and large, have a choice between cultivating field crops and growing NTFPs. Growing selected NTFP species in association with field crops has been a traditional practice in the Hills of Nepal (Neupane, 1999; Pandit, 2001). Assorted species of NTFPs grown in farmlands have been an integral component of local economies, for they are sources of food and cash earnings wherever farmers have access to market centers.

In the study area, most NTFP species in farmlands grow naturally on the edges and bonds of plots cultivated with upland crops, locally called $\underline{\mathrm{bari}^{2}}$, on the walls of gullies, in uncultivated inclusions, in swidden plots and in land under Typha angustata locally called kharbari. Almost at equal proportion farmers in both upper and lower zones have planted assorted NTFP species, which can be broadly classified into three categories: clump or grass species, tree species, and MAP species. Of the 16 widely collected NTFPs, Dendrocalamus strictus (bamboo), Arundinaria intermedia (igalo) and Thysanolaena maxima (amliso) are the commonly domesticated clump or bush species. Regarding tree species, Bassia butyracea (chiuri), Terminalia chebula (harro), Emblica officinalis (amala), Cinnamomum tamala (dalchini) and Myrica esculenta ( $\mathrm{kafal}$ ) are typical species grown on farms. Medicinal aromatic plants (MAPs) are rarely grown in both zones. Despite their stated preference for domestication (Pandit, 2003), very few farmers are grown MAPs in their farmlands. This is the reason why this study explores the factors influencing MAP domestication.

\section{Facters influencing MAP domestication}

This section identifies a number of variables, which affect the improvement in MAP domestication. The link between various socio-economic variables and number of MAP species domesticated are investigated with the help of multiple regression analysis. A stepwise multiple regression analysis was used to influence the level of NTFP domestication by a set of independent variables: $\mathrm{X}_{1} \ldots \ldots \ldots \mathrm{X}_{\mathrm{n} .}$ The regression model is specified as follows:

$\mathrm{Y}=\mathrm{b}_{\mathrm{o}}+\mathrm{b}_{1} \mathrm{X}_{1}+\mathrm{b}_{2} \mathrm{X}_{2}+\ldots \ldots \ldots \ldots \ldots \ldots \mathrm{b}_{\mathrm{n}} \mathrm{X}_{\mathrm{n}}$

Where,

$\mathrm{Y}=$ the number of individual tree species (first dependent variable).

$\mathrm{b}_{\mathrm{o}}$ is the intercept.

Rainfed upland plots cultivated regularly with cereal crops, often degraded due to uninterrupted cropping, locally called bari or pakho lands. 
$\mathrm{b}_{1}, \mathrm{~b}_{2} \ldots \ldots \ldots$ are coefficients of explanatory variables $\mathrm{X}_{1}, \mathrm{X}_{2} \ldots \ldots \mathrm{X}_{\mathrm{n}}$.

The model was constructed using the stepwise probability criteria of $F$ to enter

$\leq .05$ and probability of $\mathrm{F}$ to remove $\geq .10$.

\section{Defining variables}

Dependent variable- Model (Y): Average number of individual herbal plant species such as S. chirayita, Nardostachys grandiflora (Jatamansi), Valeriana jatamansi (Sugandawal) and Asparagus species grown by farmers.

Independent Variables- Of the total (44) variables examined in the correlation analysis, 15 variables that have linear relationship with any of the dependent variables were selected as independent variables listed in Table 4 . The influence of independent variables on the dependent variables was examined using regression analysis.

Table 4: Variables description and equation

\begin{tabular}{|c|c|c|c|c|}
\hline Variables & Variable description & B & SE & $\operatorname{Exp}(\mathrm{B})$ \\
\hline $\begin{array}{l}\text { (Constant) } \\
\text { Paddy terrace } \\
\left(\mathrm{X}_{1}\right)\end{array}$ & $\begin{array}{l}\text { Paddy terrace areas locally called khet } \\
\text { and are relatively better quality lands } \\
\text { usually owned by better-off } \\
\text { households. }\end{array}$ & $29.57^{* *}$ & 16.864 & -.001 \\
\hline $\begin{array}{l}\text { Swidden Flot } \\
\left(\mathrm{X}_{2}\right)\end{array}$ & $\begin{array}{l}\text { Area of land utilized for swiddening } \\
\text { locally called khonva. Millet, maize } \\
\text { and potato are the staple crops, with } \\
\text { some NTFP species growing naturally } \\
\text { or planted }\end{array}$ & $23.39 * *$ & 3.473 & .449 \\
\hline Fallow land $\left(\mathrm{X}_{3}\right)$ & $\begin{array}{l}\text { Length of the period during which no } \\
\text { field crops are grown in swidden plots } \\
\text { (khorika). }\end{array}$ & $-23.8 * *$ & 4.319 & -.360 \\
\hline $\begin{array}{l}\text { Rainfed upland } \\
\left(\mathrm{X}_{4}\right)\end{array}$ & $\begin{array}{l}\text { The rainfed landholding or upland crop } \\
\text { terraces cultivated with maize and } \\
\text { millet. }\end{array}$ & $50.28 * *$ & 3.431 & .613 \\
\hline Cattle $\left(\mathrm{X}_{5}\right)$ & $\begin{array}{l}\text { The actual number of heads of cattle } \\
\text { per household at the time of household } \\
\text { surveying. }\end{array}$ & -.409 & 1.198 & -.013 \\
\hline Goat $\left(\mathrm{X}_{6}\right)$ & $\begin{array}{l}\text { The actual number of heads of goat per } \\
\text { household at the time of household } \\
\text { surveying. }\end{array}$ & -.528 & .636 & -.034 \\
\hline $\begin{array}{l}\text { Difficult trading } \\
\left(\mathrm{X}_{7}\right)\end{array}$ & $\begin{array}{l}\text { The value of } 1.0 \text { was assigned if } \\
\text { farmers faced difficulty and legal } \\
\text { constraints in selling NTFPs, and zero } \\
(0.0) \text { in the absence of any such. }\end{array}$ & $-1.172^{*}$ & 9.352 & -.052 \\
\hline
\end{tabular}




\begin{tabular}{|c|c|c|c|c|}
\hline $\begin{array}{l}\text { Fear of Ranger } \\
\left(\mathrm{X}_{8}\right)\end{array}$ & $\begin{array}{l}\text { The value of } 1.0 \text { was assigned if farmers } \\
\text { expressed apprehension of being arrested } \\
\text { by any ranger while selling NTFPs, and } \\
\text { zero (0.0) in the ab sence of any such. }\end{array}$ & 8.84 & 11.546 & .029 \\
\hline $\begin{array}{l}\text { Market } \\
\text { Uncertainty }\left(\mathrm{X}_{9}\right)\end{array}$ & $\begin{array}{l}\text { The value of } 1.0 \text { was assigned if farmers } \\
\text { feel uncertainty in the marketing of } \\
\text { NTFPs, and zero }(0.0) \text { in the absence of } \\
\text { any such. }\end{array}$ & 2.415 & 10.298 & .012 \\
\hline $\begin{array}{l}\text { Long life cycle } \\
\text { (X10) }\end{array}$ & $\begin{array}{l}\text { The value of } 1.0 \text { was assigned if farmers } \\
\text { feel difficulty in integrating NTFP } \\
\text { because of long life cycle, and zero (0.0) } \\
\text { in the absence of any such }\end{array}$ & 1.915 & 6.756 & .011 \\
\hline $\begin{array}{l}\text { Inappropriate } \\
\text { policy }\left(\mathrm{X}_{11}\right)\end{array}$ & $\begin{array}{l}\text { The value of } 1.0 \text { was assigned if farmers } \\
\text { had faced problem in growing NTFP due } \\
\text { to inappropriate permit system imposed } \\
\text { by Government }\end{array}$ & -1.440 & 7.731 & -.008 \\
\hline $\begin{array}{l}\text { Free access to } \\
\text { forests }\left(\mathrm{X}_{12}\right)\end{array}$ & $\begin{array}{l}\text { The value of } 1.0 \text { was assigned if farmers } \\
\text { had free access to a forest, and zero }(0.0) \\
\text { in the absence of any such. }\end{array}$ & $16.02^{*}$ & 7.735 & .090 \\
\hline $\begin{array}{l}\text { Skill on making } \\
\text { NTFP goods } \\
\left(\mathrm{X}_{13}\right) \\
\text { Knowledge on } \\
\text { NTFP } \\
\text { domestication } \\
\left(\mathrm{X}_{14}\right)\end{array}$ & $\begin{array}{l}\text { A person without any skill of making } \\
\text { NTFP goods was scored zero }(0.0) \text { and a } \\
\text { person with skill was scored } 1 \text {. } \\
\text { A person without any knowledge on } \\
\text { NTFP domestication was scored zero } \\
\text { (0.0) and a person with skill was scored } \\
1 .\end{array}$ & 2.693 & 3.960 & .038 \\
\hline $\begin{array}{l}\text { Frequency of } \\
\text { visits to forest } \\
\text { (X15) }\end{array}$ & $\begin{array}{l}\text { This variable represents the average } \\
\text { number of monthly visits to forests by } \\
\text { members of a farm household. }\end{array}$ & $8.126^{*}$ & 2.797 & -.147 \\
\hline
\end{tabular}

Source: Field survey, 2003

$* P<0.01, * * P<0.001$

The analysis reveals that six independent variables significantly influence the cultivation of herb NTFP species (Table 4). Of the total significant variables, four variables such as "fallow land", "frequency of visit", "free access, and "difficult trading" are negatively influencing variables. Only two variables viz., "Swidden plots" and "marginal rainfed uplands" have positive relationship with domestication of MAP species. Marginal rainfed upland has highest correlation with domestication of herb species followed by "Swidden plot".

Farmers were found to avoid growing these species in paddy terraces and grow more in small plots or terrace risers of marginal upland terraces, which were not much utilized for field crop cultivation. Normally, large farm plots were being utilized for growing cereals, which are the 
major sources of food in the hills and mountains of Nepal. The other negatively influencing variables such as "difficult trading " and "free access to forest" have negatively influenced the growing of MAP species in farmlands. This is very well evident in the case of many of the medicinal aromatic plants such as $\mathrm{N}$. grandiflora and $\mathrm{V}$. jatamansi, which are considered to be illegal if harvested by the villagers. But because of the free access, they are being exploited. Therefore, there is a need to follow a strong monitoring mechanism to avoid over harvesting of MAP species.

\section{Conclusion and Recommendation}

The findings of this study have clearly indicated that the lack of appropriate institutional environment, including free access to forest, restriction on domestication of selected NTFP species, lack of extension services for disseminating technical know-how on NTFP propagation as well as for helping farmers to develop NTFP based goods making skills, absence of a well managed marketing system, is the most serious constraint for promoting MAP domestication. Any institutional reform program for promoting MAP domestication should aim at removal of these constraints. In this regard, the use and management responsibilities of national forests should be handed over to local communities in line with the national community forestry policy. Following the national leasehold forestry policy, the District Forestry Office may also hand over some of the national forests to economically most disadvantaged group of people as their leasehold forest. These actions will help to end the open access status of forests, thereby significantly reducing NTFP collection from forests and encouraging their domestication. Simultaneously, opportunities should be provided to local people for acquiring knowledge of propagation and management of different species of NTFP and for developing NTFP based goods making skills through the provision of effective extension services. Training on knowledge and skill development should be organized at villages where farmers have expressed interest in NTFP domestication, and all interested individuals, including females, should have access to such training. Particularly the techniques and methods of NTFP propagation as well as management should be imparted on farmers through the farmer's field schools, which would allow farmers to develop themselves as extension workers.

All efforts made to promote domestication of NTFP will not have any effect if farmers are not allowed to sell their produces through legal barriers or they cannot earn satisfactory income from the sales of NTFP. Legal provision should be made to allow the sale of all kinds of NTFP available from private farmlands.

To prevent the possible abuse of this provision, a simple, village based certification system has to be established, which will allow village leaders to inspect and issue certification to farmers who have produced NTFP in their private farms. Equally important is the promotion of group marketing system to enable farmers to establish a market information dissemination system and to earn satisfactory income from NTFP. Farmers will gradually shift from cereal crop cultivation to NTFP production when they are convinced that they can get attractive income from this activity. 


\section{References:}

ANSAB, 1997. Environment and Forest Enterprise Activity: Forest Products Market/Enterprise Options Study, Final Report Submitted to USAID-Nepal. Asia Network for Small Scale Agricultural Bio-resources, P.O. Box 16, Kathmandu, Nepal

Arnold, J.E.M. and Perez, M.R. 1998. The role of Non-timber Forest Products in conservation and development. In Wollenberg, E. and Ingles A., Incomes from the Forest: Methods for the development and conservation of forest products for local communities. Center for International Forestry Research and The World Conservation Union.

De Beer, J.H. and McDermott, M.J. 1996. The Economic Value of NTFPs in South East Asia. The World Conservation Union (IUCN).

Edwards, D.M. 1996. Non-timber Forest Products from Nepal: Aspects of the trade in medicinal and aromatic plants. FORESC Monograph 1/96. Forest Research and Survey Centre, Ministry of Forest and Soil Conservation, Kathmandu, Nepal.

Ellis, F. 1992. Agricultural Policies in Developing Countries. Cambridge University Press, Cambridge. UK.

Dixon, J.A., James D.E. and Sherman P.B. 1989. The economics of dryland management. Earth Scan Publication Ltd. London. Pp.109-140.

Ingles, A. W. 1998. Guiding the development of the NTFP sub-sector in Lao PDR: Towards a long-term strategy. IUCN and Department of Forestry LAO PDR.

Mittelman, Andrew J., Lai C. K., Neil B., Genevieve M. and Esther K. 1997. Non-wood forest products outlook. Study for Asia and Pacific: Towards 2010- Bangkok. Forestry Policy and Planning Division, Rome, Regional Office for Asia and the Pacific: Food and Agricultural Organization.

Olsen, C.S. 1998. The trade in medicinal and aromatic plants from central Nepal to Northern ndia. Economic Botany 52(3): 279-292.

Pandit, B.H. 2001. Non-timber forest products in shifting cultivation plots: A means of improving livelihood of Chepang hill tribes in the mountains of Nepal. Asia Pacific Journal of Rural Development, 11 (1): 1-14.

Pandit, B.H. and thapa, G.B. 2004. Poverty and Resource Degradation in the Mountains of Nepal. Society and Natural Resources, 17:1-16.

Sidhu, D.S. (1997). Measures to enhance the efficiency of agricultural marketing systems: Case of India. Marketing systems for agricultural products: A seminar report, Asian Productivity Organization, Tokyo. Pp. 104-132. 